
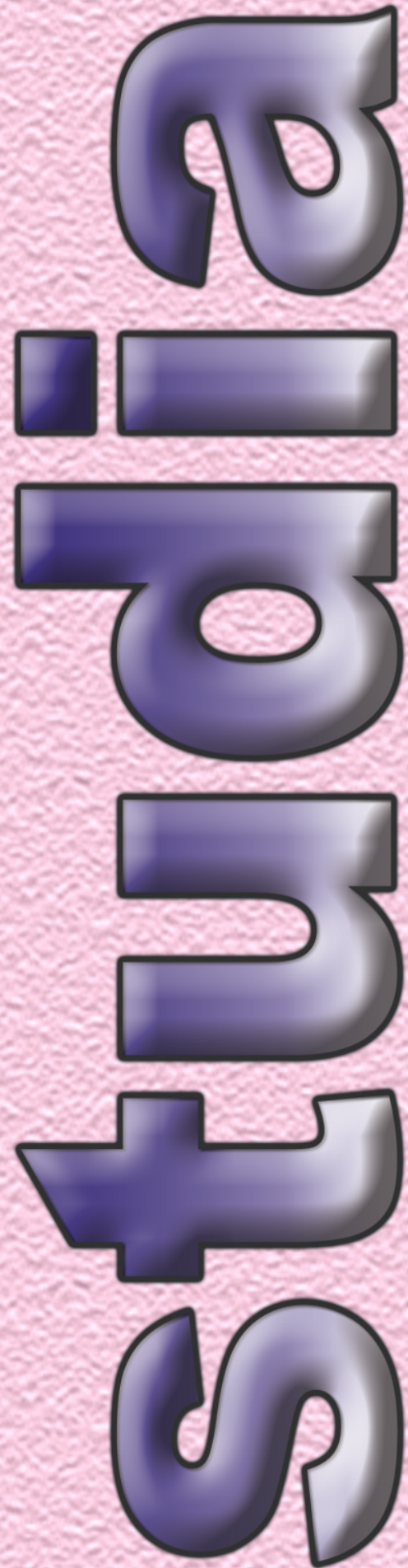

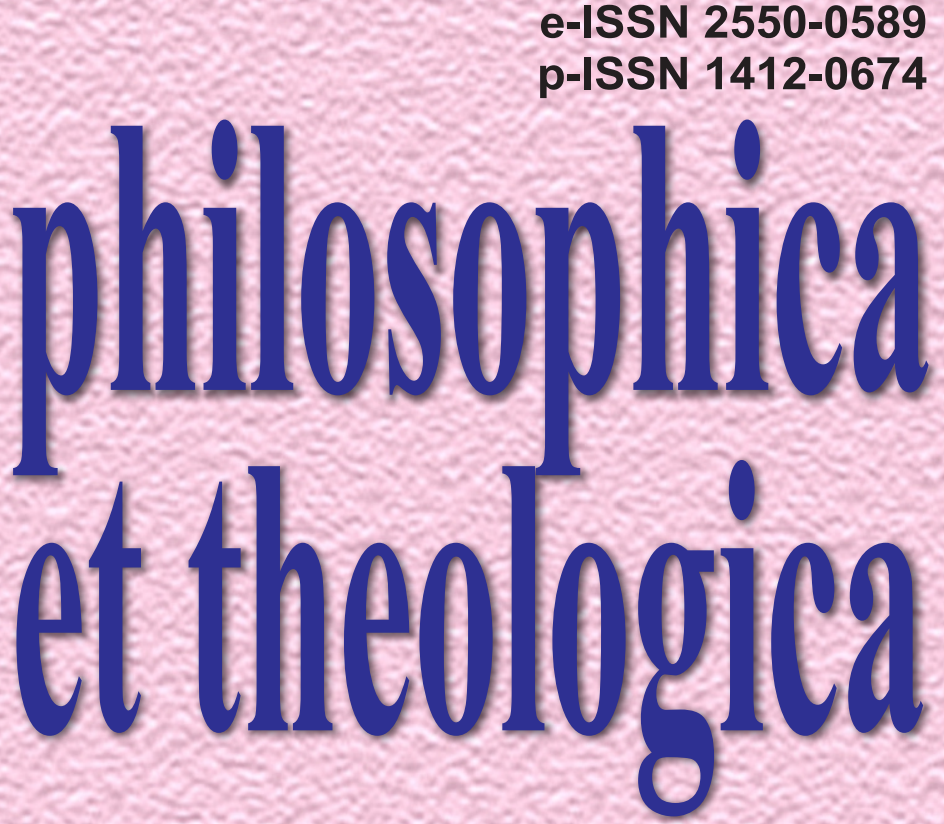

Pandemi Covid 19 dalam Perspektif Visi Kebangkitan Paus Fransiskus

Martinus Dam Febrianto

Formasi Berkelanjutan:

Membermaknakan Kekinian Imamat Edison R.L. Tinambunan

Imajinasi untuk Merawat Kemanusiaan: Pemikiran Martha Nussbaum dalam Pendidikan Humaniora Cicilia Damayanti

Diskursus Hukum Kodrat dan Problem Pascamodernitas Hizkia Fredo Valerian

Polemik Antara Original Event dan Original Purpose dalam Liturgi: Spiritualita Liturgi Ekaristi dalam Perspektif Sejarah Liturgi dan Kitab Suci Robert Pius Manik

Piet Go, Ensiklik Rerum Novarum dan Quadragesimo Anno dan Transformasi Moral Millenial Godlif Sianipar

Applying Bardach and patashnik's Poliy Concept to Educational Leadership Development Effort in the Developing World Gregorius Kukuh Nugroho *****

TELAAH BUKU 


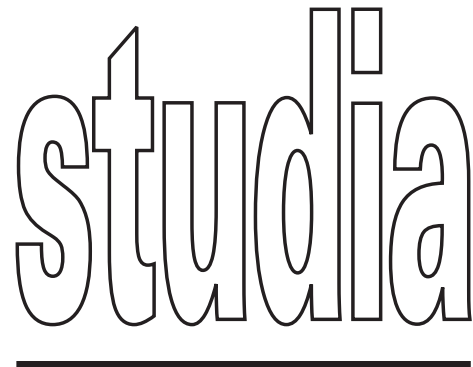

STUDIA PHILOSOPHICA ET THEOLOGICA (ISSN Print 1412-0674 and ISSN Online 2550-0589) is a bilingual (Indonesian and English language) and peer reviewed journal published by Center of Research of Widya Sasana School of Philosophy Theology, Malang. STUDIA specializes in researched papers related to contextualization and inculturation of theology and philosophy from inter-disciplinary-methodological point of view. Journal has 2 issues per year (April and October)

STUDIA welcomes philosophical and theological contributions from scholars with various background of disciplines. This journal uses English and Indonesian Language. STUDIA is an open access journal whose papers published is freely downloaded.

\section{FOCUS AND SCOPE:}

STUDIA focuses on philosophical and theological studies based on both literary and field researches. The emphasis of study is on systematic attempt of exploring seeds of Indonesian philosophy as well as contextualization and inculturationof theology in socio-political-historical atmosphere of Indonesia.

Scope of STUDIA covers various perspectives of philosophical and theological studies from interdisciplinary methodology and cultural-religious point of view of traditions.

\section{PUBLISHER :}

P3M Sekolah Tinggi Filsafat Teologi

Widya Sasana Malang

Jl. Terusan Rajabasa 2,

Malang 65146 Indonesia

Telp. 0341 - 552120

Fax. 0341 - 566676

Email : stftws@gmail.com

Website : ejournal.stftws.ac.id

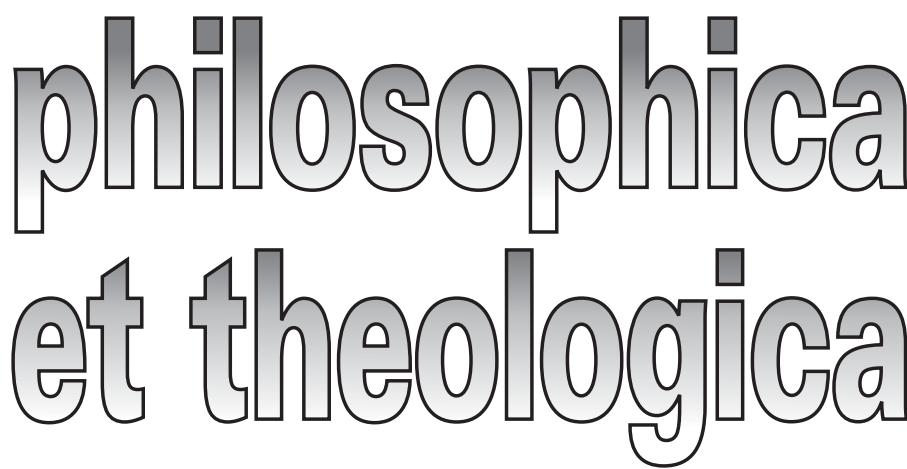

e-ISSN 2550-0589 p-ISSN 1412-0674

Editor in Chief

FX. Eko Armada Riyanto (Google Scholar; h-index: 5); Widya Sasana College of Philosophy Theology, Malang.

\section{Managing Editors}

Edison RL. Tinambunan (Google Scholar; h-index: 1); Widya Sasana College of Philosophy Theology, Malang.

Kurniawan Dwi Madyo Utomo (Google Scholar); Widya Sasana College of Philosophy Theology, Malang.

\section{Editorial Board}

Pius Pandor (Google Scholar; h-index: 2); Widya Sasana College of Philosophy Theology, Malang.

Valentinus Saeng (Google Scholar; h-index: 2); Widya Sasana College of Philosophy Theology, Malang.

Yohanes I Wayan Marianta (Google Scholar); Widya Sasana College of Philosophy Theology, Malang.

Raymundus Made Sudhiarsa (Google Scholar; h-index: 2); Widya Sasana College of Philosophy Theology, Malang.

Alphonsus Catur Raharso (Google Scholar; h-index: 2); Widya Sasana College of Philosophy Theology, Malang.

Petrus Maria Handoko (Google Scholar; h-index: 2); Widya Sasana College of Philosophy Theology, Malang.

Antonius Denny Firmanto (Google Scholar; h-index: 2); Widya Sasana College of Philosophy Theology, Malang.

Carl Sterkens (Scopus ID: ... ; Google Scholar; h-index: 7); Katholic Radboud University, Nijmegen, Niederlands.

Daniel Franklin Pilario(Google Scholar; h-index: 4); Adamson University, Manila, Philippines.

Roland Tuazon (Google Scholar; h-index: 2); Adamson University, Manila, Philippines.

Emanuel P.D. Martasudjita (Scopus ID: 6026801; Google Scholar; h-index: 4); Sanata Dharma University, Yogyakarta.

Johanis Ohoitimur (Google Scholar; h-index: 3); Pineleng College, Manado.

Antonius Eddy Kristiyanto (Google Scholar; h-index: 5); Driyarkara College, Jakarta.

Mudjia Rahardja (Scopus ID: ... Google Scholar; h-index: 10); Maulana Malik Ibrahim Islamic State University, Malang. Justinus Sudarminta (Google Scholar; h-index: 7); Driyarkara College, Jakarta.

English Language Advisor

Maria Lichmann (North Carolina)

Odilia Rahayu Widji Astuti

Indonesian Language Advisor

Didik Bagiyowinadi

Information and Technology

Imilda Retno Arum Sari

Publication Frequency

Studia Philosophicaet Theologica is published two times a year (April and October) 


\section{Studia Philosophica et Theologica}

\section{Author Guidelines}

1. Article must have150-word abstract in both English and Indonesian language and four or five keywords.

2. Article should be between 5000 and 8000 words, inclusive of references and footnotes.

3. Article must be a study based on either literary (text) or field research.

4. Article will be submitted in Word (single-spaced and 12-point font) for consideration by email attachment, beside online submission as required. Authors must $\log$ in before submit their article.

5. Headings:

- First-level headings (e.g. Introduction, Conclusion) should be in bold, with an initial capital letter for any proper nouns.

- Second-level headings should be in bold italics, with an initial capital letter for any proper nouns.

- Third-level headings should be in italics, with an initial capital letter for any propernouns.

6. Notes and Bibliographies please click https://www.dropbox.com/s/y2nb9l3cvb9 fg47/Notes\%20and\%20Bibliography\%20Turabian\%20Style.pdf? $d l=0$.

7. Article submitted will be peer-reviewed by qualified academics; this process may take weeks or months. All submitted papers are subject to review of the editors, editorial board, and reviewers.

8. Author should be willing to respond to questions from readers of their articles; and in case there is correction, author must refine the article as soon as possible.

\section{Guidelines for Book Reviews}

1. Please include, at the beginning: Author, Title, Place, Publisher, Date, number of pages, ISBN of the book reviewed.

E.g., Taylor, Charles. A Secular Age. Cambridge: The Belknap Press of Harvard University Press, 2007. 874+x pp. ISBN-13: 978-0-674-02676-6.

2. The review begin with abstract, three or four keywords and continue with a brief overall description of the book.

3. The review may include:

- The content and its complexity of the book.

- Comments on the author's style and contribution of the book.

- Philosophical or theological methodology of presentation.

- Position of the philosophical or theological arguments in its field.

4. The preferred format for submissions is MS-Word.

5. Review should be about 1500 words long. The name, affiliation and email address of the reviewer should appear at the end of the review. 


\section{Studia Philosophica et Theologica E-ISSN 2550 - 0589 \\ ISSN 1412-0674 \\ Vol. 21 No. 1 April 2021 \\ Hal. 1 - 131}

\section{DAFTAR ISI}

\section{ARTIKEL}

Pandemi Covid 19 dalam Perspektif Visi Kebangkitan

Paus Fransiskus

Martinus Dam Febrianto

$1-23$

Formasi Berkelanjutan: Membermaknakan Kekinian Imamat

Edison R.L. Tinambunan

Imajinasi untuk Merawat Kemanusiaan:

Pemikiran Martha Nussbaum dalam Pendidikan Humaniora

Cicilia Damayanti.....

Diskursus Hukum Kodrat dan Problem Pascamodernitas

Hizkia Fredo Valerian

$67-81$

Polemik Antara Original Event dan Original Purpose

dalam Liturgi: Spiritualitas Liturgi Ekaristi dalam Perspektif

Sejarah Liturgi dan Kitab Suci

Robert Pius Manik

$82-96$

Piet Go, Ensiklik Rerum Novarum dan Quadragesimo Anno dan Transformasi Moral Millenial

Godlif Sianipar.....

Applying Bardach and Patashnik's Policy Concept to Educational Leadership Development Effort in the Developing World

Gregorius Kukuh Nugroho 


\section{TELAAH BUKU}

Teologi Terlibat: Politik dan Budaya dalam Terang Teologi

Antonius Ignasius Nggino Tukan ................................................... 128 - 131 


\title{
POLEMIK ANTARA ORIGINAL EVENT DAN ORIGINAL PURPOSE DALAM LITURGI: Spiritualitas Liturgi Ekaristi dalam Perspektif Sejarah Liturgi dan Kitab Suci
}

\section{Robert Pius Manik}

STFT Wdiya Sasana Malang

Email:manikrobertpius@gmail.com

\begin{abstract}
This article discusses the basic character of the Roman liturgy and examines what the original Roman liturgical rite is that can serve as a standard for the Roman liturgical rites. Discussion about the authenticity of the Roman rites often lead to endless debate and create difficulties in practical matters when some of the rites are applied to liturgical celebrations. The analysis of the authenticity of the Roman rite in this paper will be based on the views of Edmund Bishop, an English liturgical historian. Besides using a historical approach, this article will also use a biblical study approach in exploring the basic characteristics of the Catholic liturgy, especially the Eucharist, so that a celebration of the Eucharistic liturgy can be said to be good. The views of several exegetes such as Brevard S. Childs (Old Testament) and Joachim Jeremias and Xavier Leon-Dufour (New Testament) will be used to analyze the biblical texts, especially regarding the story of the celebration of the Jewish Passover, Exodus and the story of the Last Supper in connection with the Eucharist. And, of course the opinions of contemporary liturgical historians such as Paul F. Bradshaw and John Maxwell are also very important here in order to discover the relevance of this study today.
\end{abstract}

Keywords: eucharist, liturgy, original event, original purpose, passover

\begin{abstract}
Abstrak
Makalah ini membahas tentang karakter dasar dari ritus liturgi Romawi sehingga bisa melihat apa elemen pokok atau unsur dasar yang bisa dijadikan sebagai patokan standar dari ritus liturgi Romawi. Diskusi tentang ke-asli-an ritus romawi sering kali membawa perdebatan yang tak berakhir dan menciptakan kesulitan dalam hal-hal praktis saat diterapkan dalam perayaan liturgi. ${ }^{1}$ Analisa tentang keaslian ritus Romawi dalam makalah ini akan didasarkan pada pendapat dan pandangan Edmund Bishop, seorang ahli sejarah liturgi dari Inggris. Di samping menggunakan pendekatan historis, makalah ini juga akan menggunakan pendekatan studi biblis dalam menggali
\end{abstract}


karakter dasar dari liturgi Katolik, khususnya Ekaristi hingga suatu perayaan liturgi Ekaristi itu dapat dikatakan baik. Dalam hal ini, pandangan beberapa ekseget seperti Brevard S. Childs (Perjanjian Lama) dan Joachim Jeremias dan Xavier Leon-Dufour (Perjanjian Baru) akan digunakan untuk menganalisis teksteks Kitab Suci khususnya mengenai kisah perayaan Paskah Yahudi dan Exodus serta kisah Perjamuan Malam Terakhir Yesus dalam kaitannya dengan Ekaristi. Tentunya pendapat para ahli sejarah liturgi kontemporer seperti Paul F. Bradshaw dan John Maxwell juga sangat penting di sini dengan harapan agar bisa menemukan relevansi dari studi ini untuk saat ini.

Kata Kunci: ekaristi, liturgi, original event, original purpose, paskah

\section{Pendahuluan}

Iman yang kita miliki sekarang tidak datang tiba-tiba kepada kita melainkan kita terima dari warisan sejarah Gereja yang cukup panjang. Salah satu cara mengekspresikan iman yang dimiliki Gereja itu ialah melalui liturgi (perayaan iman). Cara Gereja berliturgi mencerminkan teologi yang sedang dihayati oleh Gereja itu sendiri. Dalam artikelSome Questions about the Conceration, Jozef Lamberts mempertanyakan dasar historis dan teologis atas praktek ritual yang dilakukan sejumlah imam saat merayakan Ekaristi khususnya saat konsekrasi, misalnya saat memecahkan roti ketika konsekrasi persis seperti dilakukan Yesus dalam Injil sedangkan imam lain tidak melakukannya karena menurut rubrik hal itu dilakukan kemudian. ${ }^{2}$ Persoalan pokoknya bukan soal kapan saat yang tepat untuk memecahkan roti, tetapi lebih kepada persoalan "original" yakni apakah liturgi itu soal "original events" atau "original purpose"? Dengan mendalami isu ini, artikel ini melacak poin penting dalam liturgi Ekaristi dalam Gereja Katolik yakni apa elemen pokok atau unsur mendasar dari Liturgi Ekaristi Gereja Katolik, dan dengan demikian akan membantu umat dan semua praktisi liturgi mengerti dan menghayati Ekaristi dan relevansinya untuk hidup kongkret. Makalah ini tidak akan mengulas seputar konsekrasi tetapi mencoba menggali apa karakter mendasar dari ritus liturgi Romawi dengan maksud agar menemukan penekanan teologis apa yang sedang dihayati oleh Gereja saat ini (khususnya Ekaristi) dan dengan demikian diharapkan bisa mencari relevansi iman (liturgi) untuk konteks saat ini yang belakangan ini termasuk menjadi sorotan para pemerhati liturgi. ${ }^{3}$

1 Hadley, Christopher M. “The Archetypal Faith of Christ." Theological Studies 81. No.3 (September 2020): 671-692, at 689.

2 Jozef Lamberts, "Some Questions about the Consecration" in Worship, vo. 94, (January 2020): 50-66, at 50-51.

3 Nathan P. Chase, "Liturgical Preservation, Innovation, and Exchange at the Crossroads of the Visigothic and Merovingian Kingdoms" in Worship, 92, (September 2018): 415-435, at 435. 
Dalam makalah ini penulis akan mendalami makna liturgi berdasarkan perayaan liturgi Paskah Yahudi (Perjanjian Lama) dan Kisah Malam Perjamuan Terakhir Yesus (Perjanjian Baru). Kemudian secara umum meninjau sejarah perjalanan (evolusi) perayaan Ekaristi dalam tradisi ritus Romawi, dan kemudian merefleksikan relevansinya untuk Gereja saat ini.

\section{Perjanjian Lama dan Liturgi: Kisah Exodus dan Perayaan Paskah}

Dalam analisa biblisnya mengenai kaitan antara perayaan-perayaan liturgi bangsa Israel dan teks-teks Kitab Suci khususnya Perjanjian Lama, Brevard S. Childs mengatakan bahwa bangsa Israel merayakan perayaanperayaan liturgi karena mereka sadar dan ingat akan karya keselamatan dari Allah. ${ }^{4}$ Childs menekankan bahwa Kitab Suci merupakan Wahyu Allah yang mengungkapkan karya keselamatan dari Allah. ${ }^{5}$ Inisiatif untuk menyelamatkan manusia pertama-tama datang dari Allah yang ingin membangun relasi kembali dengan manusia setelah jatuh ke dalam dosa. Tanggapan bangsa Israel atas inisiatif dari Allah itu juga diekspresikan dalam berbagai peristiwa termasuk lewat perayaan-perayaan (liturgi). Perayaanperayaan liturgi itu direfleksikan dalam terang iman dan juga dituangkan dalam bentuk narasi/teks yang dituliskan sebagaimana kita miliki dalam Kitab Suci. Maka Childs melihat teks Keluaran 12:1-13:16 sebagai teks liturgi, bukan teks sejarah tentang salah satu gerenasi bangsa Israel sedang berangkat meninggalkan perbudakan di Mesir. ${ }^{6}$

Untuk Childs, semua kisah bangsa Israel dalam Kitab Suci bukanlah laporan sejarah, melainkan refleksi iman akan Perjanjian (covenant) antara Allah dengan Israel. Perjanjian yang diadakan oleh Allah dan bangsa Israel memiliki dua arah, yakni dari pihak Allah: Allah akan selalu menyelamatkan bangsa Israel dan memberkati mereka, dan dari pihak bangsa Israel: bangsa Israel harus taat kepada-Nya sebagai satu-satunya Allah mereka. Maka, menurut Childs, setiap peristiwa yang dialami bangsa Israel sebagaimana dikisahkan dalam Kitab Suci selalu berkaitan dengan kisah karya penyelamatan dari Allah dan tanggapan/refleksi bangsa Israel akan karya Allah itu. ${ }^{7}$

Childs mengatakan bahwa kisah tentang ritual perayaan Malam Paskah dalam Keluaran 12:1-14 merupakan naskah liturgi tentang ritual yang harus dilakukan bangsa Israel ketika merayakan paskah dan sekali lagi ditekankan bahwa kisah itu bukan tentang satu generasi bangsa Israel yang akan

4 Brevard S. Childs, Introduction to the Old Testament as Scripture (Philadelphia: Fortress Press, 2011), 73.

5 Ibid., 76.

6 Ibid., 172.

7 Ibid., 73-76. 
berangkat meninggalkan Mesir, melainkan kisah tentang semua generasi bangsa Israel yang diselamatkan oleh Allah. ${ }^{8}$

\begin{abstract}
${ }^{1}$ Berfirmanlah TUHAN kepada Musa dan Harun di tanah Mesir: ${ }^{2 " B u l a n}$ inilah akan menjadi permulaan segala bulan bagimu; itu akan menjadi bulan pertama bagimu tiap-tiap tahun. ${ }^{3}$ Katakanlah kepada segenap jemaah Israel: Pada tanggal sepuluh bulan ini diambillah oleh masing-masing seekor anak domba, menurut kaum keluarga, seekor anak domba untuk tiap-tiap rumah tangga. ${ }^{4}$ Tetapi jika rumah tangga itu terlalu kecil jumlahnya untuk mengambil seekor anak domba, maka ia bersama-sama dengan tetangganya yang terdekat ke rumahnya haruslah mengambil seekor, menurut jumlah jiwa; tentang anak domba itu, kamu buatlah perkiraan menurut keperluan tiap-tiap orang. ${ }^{5}$ Anak dombamu itu harus jantan, tidak bercela, berumur setahun; kamu boleh ambil domba atau kambing. ${ }^{6} \mathrm{Kamu}$ harus mengurungnya sampai hari yang keempat belas bulan ini; lalu seluruh jemaah Israel yang berkumpul, harus menyembelihnya pada waktu senja. ${ }^{7}$ Kemudian dari darahnya haruslah diambil sedikit dan dibubuhkan pada kedua tiang pintu dan pada ambang atas, pada rumah-rumah di mana orang memakannya. ${ }^{8}$ Dagingnya harus dimakan mereka pada malam itu juga; yang dipanggang mereka harus makan dengan roti yang tidak beragi beserta sayur pahit. 9 Janganlah kamu memakannya mentah atau direbus dalam air; hanya dipanggang di api, lengkap dengan kepalanya dan betisnya dan isi perutnya. ${ }^{10}$ Janganlah kamu tinggalkan apa-apa dari daging itu sampai pagi; apa yang tinggal sampai pagi kamu bakarlah habis dengan api. ${ }^{11}$ Dan beginilah kamu memakannya: pinggangmu berikat, kasut pada kakimu dan tongkat di tanganmu; buru-burulah kamu memakannya; itulah Paskah bagi TUHAN. ${ }^{12}$ Sebab pada malam ini Aku akan menjalani tanah Mesir, dan semua anak sulung, dari anak manusia sampai anak binatang, akan Kubunuh, dan kepada semua allah di Mesir akan Kujatuhkan hukuman, Akulah, TUHAN. ${ }^{13}$ Dan darah itu menjadi tanda bagimu pada rumah-rumah di mana kamu tinggal: Apabila Aku melihat darah itu, maka Aku akan lewat dari pada kamu. Jadi tidak akan ada tulah kemusnahan di tengah-tengah kamu, apabila Aku menghukum tanah Mesir. ${ }^{14}$ Hari ini akan menjadi hari peringatan bagimu. Kamu harus merayakannya sebagai hari raya bagi TUHAN turun-temurun. Kamu harus merayakannya sebagai ketetapan untuk selamanya.
\end{abstract}

Kisah Keluaran 12:1-14 ini adalah semacam 'manual' (teks panduan) liturgi yang berlaku untuk semua generasi bangsa Israel. Alasan ritus liturgi tersebut diletakkan pada kisah pembebasan bangsa Israel dari Mesir atas intervensi Allah ialah agar liturgi Paskah yang dirayakan oleh semua bangsa Israel mendapat 'otoritas'. ${ }^{9}$

Childs menemukan bahwa komposisi dari kisah Exodus bangsa Israel dan perayaan Paskah dalam Keluaran 12:1-13:16 berasal dari banyak tradisi, termasuk tradisi nomadic di mana 'bangsa Israel' belum mengenal Mesir, belum mengenal dunia pertanian (belum mengenal roti gandum-matzah), dan sekaligus juga dalam teks itu ada terdapat pengaruh tradisi sesudah bangsa Israel keluar dari Mesir di mana mereka sudah mengenal dunia pertanian.

8 Ibid., 176.

9 Ibid., 172. 
Indikasinya dapat terlihat dari kisah tentang ritus/ritual perjamuan Paskah bangsa Yahudi dalam Kitab Suci yang menyebutkan elemen-elemen pokok ritual paskah seperti: domba (nomadic tradition), roti tak beragi dan anggur (agricultural tradition). Dengan demikian, Childs menyimpulkan bahwa kisah Exodus dalam Keluaran 12:1-13-16 bukanlah kisah tentang satu generasi bangsa Israel yang hidup pada zaman Musa yang dibebaskan oleh Allah keluar dari perbudakan Mesir. Kisah itu merupakan kisah tentang semua generasi bangsa Israel yang terikat dengan Perjanjian dengan Allah. ${ }^{10}$

Childs mengatakan bahwa setiap orang Israel yang merayakan Paskah sesuai dengan ritual yang ditentukan mempunyai pengalaman keselamatan exodus yang kualitasnya sama dengan yang dialami bangsa Israel bersama Musa. Gerenasi bangsa Israel yang hidup pada zaman Musa yang keluar dari Mesir tidaklah lebih istimewa dari bangsa Israel generasi-generasi berikutnya. Maka di sini, kisah Exodus, menurut Childs, bukanlah original event (peristiwa asli). Demikian juga kisah-kisah lainnya tentang karya keselamatan dari Allah dalam Kitab Suci tidak bisa dikatakan sebagai original events yang dijadikan patokan atau standar formula untuk liturgi. Kisah Exodus, menurut Childs, adalah kisah semua generasi bangsa Israel yang diselamatkan oleh Allah. ${ }^{11}$

Bangsa Israel tidak menggunakan liturgi untuk menarik peristiwa masa lampau (past event) masuk/hadir ke saat ini (present event), tetapi menggunakan liturgi untuk membawa semua generasi bangsa Israel masuk ke dalam Perjanjian kekal (eternal covenant). Liturgi yang dihayati bangsa Israel berguna untuk mengenang (zikkaron) karya keselamatan Allah bagi semua generasi Israel. Kenangan (zikkaron) akan karya keselamatan dari Allah yang dirayakan orang Israel dalam liturgi bukanlah sekedar aktivitas batin, bukan aktivitas psikologis, dan juga bukan imajinasi/pikiran, melainkan aktivitas nyata tindakan kongkret yang menghadirkan keselamatan dari Allah secara obyektif. Maka, merayakan liturgi yang sesuai dengan aturan-aturan yang sudah ditetapkan bagi orang Israel sama dengan masuk dan mengambil bagian dalam Perjanjian kekal, yakni masuk dalam karya keselamatan yang datang dari Allah.

Liturgi bagi orang Israel memiliki dua aspek yaitu aspek katabasis dan anabasis. Aspek katabasis ialah perayaan liturgi merupakan karya keselamatan dari Allah sendiri, dan aspek anabasis ialah perayaan liturgi merupakan ungkapan ketaatan umat Israel atas karya keselamatan dari Allah. Dua aspek ini juga membuat kualitas karya keselamatan yang dirayakan oleh bangsa Israel dalam setiap perayaan liturgi sama dengan kualitas karya keselamatan saat peristiwa exodus yang dulu pernah dialami nenek moyang mereka.

10 Brevard S. Child, Memory and Tradition in Israel (London: SCM Press, 1962), 31-34. See, Julius Wellhausen, Prolegomena to the History of Israel, trans. by J. Sutherland Black and Allan Menzies (Edinburg: A \& C Black, 1885), 92-93.

11 Brevard S. Childs, Exodus: A Commentary (London: SCM Press, 1974), 204. 
Ketika orang Yahudi membacakan kisah Exodus dalam perayaan liturgi, atau ketika seorang bapak Yahudi (pemimpin keluarga) menuturkan kisah Exodus dalam perjamuan malam paskah (pesach seder), mereka tidak sedang berbicara tentang masa lampau, melainkan sedang berbicara tentang kehadiran karya keselamatan dari Allah saat ini dan di sini. Bangsa Israel tidak menggunakan liturgi untuk melestarikan masa lalu. Bangsa Israel tidak menggunakan liturgi untuk mempertahankan perayaan-perayaan pesta/festival masa lampau. Bangsa Israel tidak menggunakan liturgi untuk mempertahankan ritual itu sendiri. Masa lampau tidak lebih istimewa dari masa kini. Orang Yahudi selalu merayakan iman mereka saat ini dan di sini. Tidak ada 'original event' (peristiwa asli), yang ada adalah original purpose (maksud/rencana asli) dari Allah yaitu: Allah menyelamatkan. Childs mengatakan bahwa Allah hanya mempunyai satu tindakan yaitu: menyelamatkan. ${ }^{12}$

Childs juga menjelaskan bahwa dalam konteks masa liturgi (liturgical time),bangsa Yahudi tidak mengenal masa lampau, masa 'kini' dan masa mendatang, karena pemisahan waktu seperti itu dianggap membatasi liturgi itu sendiri serta menurunkan wibawa liturgi melulu sebagai aktifitas manusia yang terikat dan dibatasi oleh ruang dan waktu. Liturgical time yang dipahami dan dihayati oleh bangsa Israel adalah berkaitan dengan waktu yang dimiliki oleh Allah sendiri. Maka menurut orang Israel, Allah tidak mempunyai masa lampau dan juga tidak mempunyai masa depan. Allah, bagi mereka, hanya mempunyai satu waktu yaitu eternal time (waktu yang kekal) dan eternal time itu selalu Present. Di hadapan Allah segala sesuatu adalah Present, Kini Sekarang dan di sini (hic et nunc). Maka karya keselamatan yang dirayakan dalam setiap perayaan liturgi adalah karya keselamatan yang hadir kini sekarang dan di sini.

Kisah exodus bangsa Israel dari Mesir yang dipimpin oleh Musa yang kita temukan dalam Kejadian 12:1-13:16 harus dibaca sebagai kisah tentang semua generasi bangsa Israel, bukanlah kisah tentang satu generasi yang berhasil merdeka dari perbudakan. Setiap generasi bangsa Israel sama istimewanya di hadapan Allah, dan semua generasi mempunyai peluang yang sama untuk mendapatkan keselamatan. Dalam perayaan liturgi, keselamatan yang diterima oleh setiap generasi sama kualitasnya dengan keselamatan exodus. Bagi bangsa Israel, menolak melaksanakan liturgi atau tidak melaksanakan liturgi sesuai dengan yang diamanatkan oleh Allah dalam Taurat sama dengan menolak keselamatan itu sendiri.

\section{Perjanjian Baru: Malam Perjamuan Yesus dan Ekaristi}

Seperti halnya Perjanjian Lama, teks-teks dan kisah Perjanjian Baru juga

12 Child, Memory and Tradition in Israel, 55-57. 
ditulis dalam konteks refleksi iman, dan para ekseget perjanjian baru tentunya tidak menggunakan teks-teks itu untuk merekonstruksi sebuah sejarah melainkan fokus pada pesan teologisnya. Demikian juga dengan kisah Malam Perjamuan Terakhir Yesus dalam keempat Injil (Mat 26:26-29; Mrk 14:22-25; Lk 22:14-20, Yoh 13:1-20) dan surat Rasul Paulus kepada jemaat di Korintus (1Kor 11:23-26) tidak dibaca sebagai sebuah laporan historis, melainkan sebuah refleksi iman Gereja atas keselamatan yang dibawa oleh Yesus. Para ahli sejarah liturgi juga melakukan studi tentang kisah Malam Perjamuan Terakhir Yesus dengan bantuan para ekseget Perjanjian Baru dengan maksud untuk melihat hubungan antara kisah tersebut dengan Liturgi khususnya Ekaristi. Mereka (Para ekseget dan ahli sejarah liturgi) ternyata belum bisa memastikan apakah kisah Malam Perjamuan Terakhir Yesus itu merupakan malam perjamuan Paskah atau tidak.

Belum ada kepastian yang tegas apakah kisah Perjamuan Malam Terakhir yang dirayakan oleh Yesus adalah perayaan Ekaristi atau tidak. ${ }^{13}$ Joachim Jeremias, misalnya, cenderung mengatakan kisah Malam Perjamuan Terakhir adalah kisah perjamuan Paskah, karena teks-teks Injil sendiri mengatakan bahwa konteksnya adalah persiapan pesta paskah Yahudi (Mat 26:2,18,19; Mrk 14:1,12,14; Lk 22:1,8,11). ${ }^{14}$ Sedangkan Leon Dufour cenderung mengatakan kisah itu bukan malam perjamuan Malam Paskah Yahudi karena absennya elemen pokok perayaan paskah yakni domba, serta tidak jelasnya ritual yang dipakai oleh Yesus saat itu kecuali memecahkan roti dan membagikan piala (anggur) yang merupakan cara kebiasaan makan orang Yahudi sehari-hari termasuk di luar pesta paskah. ${ }^{15}$ Paul Bradshaw dan Max Johnson berpendapat bahwa zaman Yesus belum ada standar baku dan formulasi/rumusan doa dan ritual yang sudah pasti mengenai detail pelaksanaan perjamuan paskah, dan karena masing-masing komunitas Yahudi yang di perantauan (diaspora) memiliki rumusan, formulasi dan ritualnya sendiri-sendiri yang sudah diadaptasi dengan kebutuhan mereka di tempat masing-masing. ${ }^{16}$ Tidak heran bila kita menemukan adanya perbedaan versi dari masing-masing Injil dalam mengisahkan Perjamuan Malam Terakhir Yesus. Yang cukup berbeda misalnya Injil Yohanes yang lebih fokus pada kisah pembasuhan kaki dari pada kisah memecahkan roti dan membagikan piala berisi anggur. Paulus dalam 1 Kor 11:23-26 sama sekali tidak menyebutkan bahwa Malam Perjamuan Terakhir Yesus berada dalam konteks perayaan paskah.

13 Paul F. Bradshaw and Maxwell E. Johnson, The Eucharistic Liturgies: Their Evolution and Interpretation (Collegeville, MN: Liturgical Press, 2012), 121-23.

14 Joachim Jeremias, The Eucharistic Words of Jesus, trans. by Norman Perrin (London: SCM Press, 1966), 62.

15 Xavier Léon-Dufour, Sharing the Eucharistic Bread: the Witness of the New Testament, trans. by Matthew J. O'Connell (Mahwah, NJ: Paulist Press, 1987), 84, 89-90.

16 Paul F. Bradshaw and Maxwell E. Johnson, The Eucharistic Liturgies, 121-23. 
Teks Perjanjian Baru sendiri mempunyai versinya masing-masing dalam mengisahkan kisah Perjamuan Terakhir Yesus. Perbedaan versi ini mengindikasikan perbedaan penekanan teologis dari masing-masing komunitas di mana kisah itu digunakan sebagai bagian dari ibadat. Injil Yohanes misalnya menekankan kisah pembasuhan kaki, Lukas dan 1 Korintus menggunakan rumusan anamnesis sedangkan Matius dan Markus tidak menyebutkan rumusan anamnesis. Perbedaan versi dalam mengisahkan Perjamuan Malam Terakhir Yesus ini mengundang pertanyaan seperti apa sebenarnya ritual itu dilaksanakan oleh Yesus, apakah memang ada berbagai macam versi ritual perjamuan Paskah? Mengapa ada perbedaan versi kisah Perjamuan Malam Terakhir Tuhan Yesus? Berikut ini kita bisa melihat dan membandingkan bagaimana kisa Perjamuan Malam Terakhir dituliskan dalam Perjanjian Baru.

\begin{tabular}{|c|c|c|c|}
\hline Mat 26:26-29 & Mrk 14:22-25 & Lk 22:14-20 & 1Kor 11:23-26 \\
\hline $\begin{array}{l}{ }^{26} \text { Dan ketika } \\
\text { mereka sedang } \\
\text { makan, Yesus } \\
\text { mengambil roti, } \\
\text { mengucap berkat, } \\
\text { memecah- } \\
\text { mecahkannya } \\
\text { lalu } \\
\text { memberikannya } \\
\text { kepada murid- } \\
\text { murid-Nya dan } \\
\text { berkata: } \\
\text { "Ambillah, } \\
\text { makanlah, inilah } \\
\text { tubuh-Ku." }{ }^{27} \\
\text { Sesudah itu Ia } \\
\text { mengambil } \\
\text { cawan, } \\
\text { mengucap syukur } \\
\text { lalu } \\
\text { memberikannya } \\
\text { kepada mereka } \\
\text { dan berkata: } \\
\text { "Minumlah, } \\
\text { kamu semua, dari } \\
\text { cawan ini. }{ }^{28} \\
\text { Sebab inilah } \\
\text { darah-Ku, darah } \\
\text { perjanjian, yang } \\
\text { ditumpahkan } \\
\text { bagi banyak } \\
\text { orang untuk } \\
\text { pengampunan }\end{array}$ & $\begin{array}{l}{ }^{22} \text { Dan ketika } \\
\text { Yesus dan murid- } \\
\text { murid-Nya } \\
\text { sedang makan, } \\
\text { Yesus mengambil } \\
\text { roti, mengucap } \\
\text { berkat, memecah- } \\
\text { mecahkannya lalu } \\
\text { memberikannya } \\
\text { kepada mereka } \\
\text { dan berkata: } \\
\text { "Ambillah, inilah } \\
\text { tubuh-Ku." }{ }^{23} \\
\text { Sesudah itu Ia } \\
\text { mengambil } \\
\text { cawan, mengucap } \\
\text { syukur lalu } \\
\text { memberikannya } \\
\text { kepada mereka, } \\
\text { dan mereka } \\
\text { semuanya minum } \\
\text { dari cawan itu. }{ }^{24} \\
\text { Dan Ia berkata } \\
\text { kepada mereka: } \\
\text { "Inilah darah-Ku, } \\
\text { darah perjanjian, } \\
\text { yang } \\
\text { ditumpahkan bagi } \\
\text { banyak orang. }{ }^{25} \\
\text { Aku berkata } \\
\text { kepadamu: } \\
\text { Sesungguhnya } \\
\text { Aku tidak akan }\end{array}$ & $\begin{array}{l}{ }^{14} \text { Ketika tiba } \\
\text { saatnya, Yesus } \\
\text { duduk makan } \\
\text { bersama-sama } \\
\text { dengan rasul- } \\
\text { rasul-Nya. }{ }^{15} \text { Kata- } \\
\text { Nya kepada } \\
\text { mereka: "Aku } \\
\text { sangat rindu } \\
\text { makan Paskah ini } \\
\text { bersama-sama } \\
\text { dengan kamu, } \\
\text { sebelum Aku } \\
\text { menderita. }{ }^{16} \text { Sebab } \\
\text { Aku berkata } \\
\text { kepadamu: Aku } \\
\text { tidak akan } \\
\text { memakannya lagi } \\
\text { sampai ia beroleh } \\
\text { kegenapannya } \\
\text { dalam Kerajaan } \\
\text { Allah." } 17 \\
\text { Kemudian Ia } \\
\text { mengambil sebuah } \\
\text { cawan, mengucap } \\
\text { syukur, lalu } \\
\text { berkata: "Ambillah } \\
\text { ini dan bagikanlah } \\
\text { di antara kamu. }{ }^{18} \\
\text { Sebab Aku berkata } \\
\text { kepada kamu: } \\
\text { mulai dari } \\
\text { sekarang ini Aku }\end{array}$ & $\begin{array}{l}{ }^{22} \text { Apakah kamu } \\
\text { tidak mempunyai } \\
\text { rumah sendiri } \\
\text { untuk makan dan } \\
\text { minum? Atau } \\
\text { maukah kamu } \\
\text { menghinakan } \\
\text { Jemaat Allah dan } \\
\text { memalukan orang- } \\
\text { orang yang tidak } \\
\text { mempunyai apa- } \\
\text { apa? Apakah yang } \\
\text { kukatakan kepada } \\
\text { kamu? Memuji } \\
\text { kamu? Dalam hal } \\
\text { ini aku tidak } \\
\text { memuji. }{ }^{23} \text { Sebab } \\
\text { apa yang telah } \\
\text { kuteruskan } \\
\text { kepadamu, telah } \\
\text { aku terima dari } \\
\text { Tuhan, yaitu } \\
\text { bahwa Tuhan } \\
\text { Yesus, pada } \\
\text { malam waktu Ia } \\
\text { diserahkan, } \\
\text { mengambil rotii }{ }^{24} \\
\text { dan sesudah itu Ia } \\
\text { mengucap syukur } \\
\text { atasnya; Ia } \\
\text { memecah- } \\
\text { mecahkannya dan } \\
\text { berkata: "Inilah }\end{array}$ \\
\hline
\end{tabular}




\begin{tabular}{|c|c|c|c|}
\hline $\begin{array}{l}\text { dosa. }{ }^{29} \text { Akan } \\
\text { tetapi Aku } \\
\text { berkata } \\
\text { kepadamu: mulai } \\
\text { dari sekarang } \\
\text { Aku tidak akan } \\
\text { minum lagi hasil } \\
\text { pokok anggur ini } \\
\text { sampai pada hari } \\
\text { Aku } \\
\text { meminumnya, } \\
\text { yaitu yang baru, } \\
\text { bersama-sama } \\
\text { dengan kamu } \\
\text { dalam Kerajaan } \\
\text { Bapa-Ku." }\end{array}$ & $\begin{array}{l}\text { minum lagi hasil } \\
\text { pokok anggur } \\
\text { sampai pada hari } \\
\text { Aku meminumnya, } \\
\text { yaitu yang baru, } \\
\text { dalam Kerajaan } \\
\text { Allah." }\end{array}$ & $\begin{array}{l}\text { tidak akan minum } \\
\text { lagi hasil pokok } \\
\text { anggur sampai } \\
\text { Kerajaan Allah } \\
\text { telah datang." } 19 \\
\text { Lalu Ia mengambil } \\
\text { roti, mengucap } \\
\text { syukur, memecah- } \\
\text { mecahkannya dan } \\
\text { memberikannya } \\
\text { kepada mereka, } \\
\text { kata-Nya: "Inilah } \\
\text { tubuh-Ku yang } \\
\text { diserahkan bagi } \\
\text { kamu; perbuatlah } \\
\text { ini menjadi } \\
\text { peringatan akan } \\
\text { Aku." }{ }^{20} \text { Demikian } \\
\text { juga dibuat-Nya } \\
\text { dengan cawan } \\
\text { sesudah makan; Ia } \\
\text { berkata: "Cawan } \\
\text { ini adalah } \\
\text { perjanjian baru } \\
\text { oleh darah-Ku, } \\
\text { yang } \\
\text { ditumpahkan bagi } \\
\text { kamu. }\end{array}$ & $\begin{array}{l}\text { tubuh-Ku, yang } \\
\text { diserahkan bagi } \\
\text { kamu; perbuatlah } \\
\text { ini menjadi } \\
\text { peringatan akan } \\
\text { Aku!" }{ }^{25} \text { Demikian } \\
\text { juga Ia mengambil } \\
\text { cawan, sesudah } \\
\text { makan, lalu } \\
\text { berkata: “Cawan } \\
\text { ini adalah } \\
\text { perjanjian baru } \\
\text { yang dimeteraikan } \\
\text { oleh darah-Ku; } \\
\text { perbuatlah ini, } \\
\text { setiap kali kamu } \\
\text { meminumnya, } \\
\text { menjadi } \\
\text { peringatan akan } \\
\text { Aku!"26 Sebab } \\
\text { setiap kali kamu } \\
\text { makan roti ini dan } \\
\text { minum cawan ini, } \\
\text { kamu } \\
\text { memberitakan } \\
\text { kematian Tuhan } \\
\text { sampai Ia datang. }\end{array}$ \\
\hline
\end{tabular}

Bradshaw cenderung mengatakan kisah Malam Perjamuan Terakhir Yesus adalah perayaan Ekaristi karena kisah itu ditulis pada zaman Kristen perdana untuk kebutuhan jemaat (perdana) di mana mereka sudah melihat kebiasaan makan bersama dan acara memecahkan roti dengan ritual khasnya (mengambil roti, mengucap berkat, memecahkan, membagikannya) sebagai tradisi istimewa jemaat saat itu yang dikemudian hari dipahami sebagai perayaan Ekaristi. ${ }^{17}$ Bradshaw misalnya mengatakan bahwa jemaat perdana masih belum mempunyai naskah Kitab Suci Perjanjian Baru seperti yang kita miliki saat ini, mereka menggunakan Kitab Suci yang sama digunakan oleh orang Yahudi ("Perjanjian Lama") dan kemudian merefleksikan hidup dan iman kristiani mereka dalam bingkai Kitab Suci "Perjanjian Lama" itu. Maka, ketika mereka mempunyai kebiasaan baru yaitu berkumpul dan memecahkan roti, kebiasaan itu kemudian direfleksikan dalam terang Kitab Suci (PL) yakni sebagai perayaan paskah yang baru. Itu sebabnya kisah Malam Perjamuan

17 Paul F. Bradshaw, The Search for the Origins of Christian Worship: Source and Methods for the Study of Early Liturgy, 2nd ed. (Oxford: Oxford University Press, 2002), 132-133. 
Terakhir Yesus diletakkan oleh para penulis Injil dalam konteks "Paskah", dan "Paskah" itu adalah paskah baru yaitu paskah Kristiani. Seperti telah dikatakan sebelumnya, Paulus dalam 1 Korintus 11:23-26 tidak meletakkan kisah Perjamuan Malam Terakhir Yesus dalam konteks perjamuan Paskah. ${ }^{18}$ Diskusi dan perdebatan tentang keaslian kisah Perjamuan Malam Terakhir ini masih belum terpecahkan hingga sekarang, tetapi hampir semua ahli sepakat bahwa kisah Malam Perjamuan Terakhir itu harus dibaca dalam konteks perayaan kultus dan liturgis (cultic account and liturgical report). ${ }^{19}$

Para exegete Perjanjian Baru dan ahli sejarah liturgi (Jeremias, Leon Dufour, Bradshaw, Johnson) mengatakan bahwa memang kisah Malam Perjamuan Terakhir dalam Perjanjian Baru dituliskan dalam konteks ritus liturgi (cultic ritual of liturgy) tetapi para penulis Injil dan Rasul Paulus (1 Kor 11) tidak bermaksud untuk menciptakan suatu formula/rumusan standard perayaan Ekaristi. Sama seperti Childs (exegete PL), para exegete Perjanjian Baru dan ahli sejarah liturgi tidak melihat kisah Perjamuan Malam Terakhir Yesus sebagai original event yang harus dijadikan sebagai manual ('teks pegangan') dan standard patokoan ritual dan rumusan-rumusan perayaan Ekaristi.

\section{Liturgi sebagai ekspresi iman (the Genius of the Roman Rite)}

Edmund Bishop adalah seorang ahli sejarah liturgi dari Inggris yang hidup pada sekitar ahir abad ke-19 hingga awal abad 20. Sebuah karya tulisnya yang berjudul "The Genius of the Roman Rite" dalam Liturgica Storica: Papers on the Liturgy and Religious Life of the Western Church (1899), memberi pengaruh sangat kuat terhadap studi sejarah liturgi Gereja khususnya dalam memahami karakteristik ritus-ritus Romawi. Yang dimaksudkan oleh Edmund Bishop dengan "Genius" bukanlah soal kecerdasan intelektual atau keterampilan berpikir, melainkan merujuk kepada mitologi kuno. "Genius" adalah putra dari satu dewa dan "Genius" adalah bapa dari semua manusia. Maka, pengertian dari istilah 'Genius' dalam tulisan Bishop itu adalah titik awal atau poin yang paling asli dan asali dari ritus Romawi. ${ }^{20}$ Dalam hal ini, titik awal/poin paling asli dan asali yang dimaksudkan oleh Bishop merujuk pada semangat penggerak (spirit) yang menjiwai munculnya ritual-ritual liturgi Romawi. Bishop lalu membuat penelitian sejarah ritus-ritus liturgi Romawi mulai dari zaman Gereja perdana sampai abad 19.

Bishop menemukan bahwa ritus liturgi Romawi yang dipakai oleh Gereja Katolik Roma pada masa hidupnya merupakan hasil evolusi yang panjang

18 Bradshaw and Johnson, The Eucharistic Liturgies, 23.

19 Paul F. Bradshaw, Eucharistic Origins (London: SPCK, 2004), 14. Xavier Léon-Dufour, Sharing the Eucharistic Bread, 94.

20 Edmund Bishop, "The Genius of the Roman Rite," in Liturgica Historica: Paper on the Liturgy and Religious Life of the Western Church (Oxford: Clarendon Press, 1918,1962), 2. 
dan sudah merupakan hasil adaptasi dan penyesuaian dari berbagai macam ritus yang ada dalam sejarah Gereja, mulai dari ritus Gereja-gereja lokal yang tersebar di Eropa pada abad-abad awal Gereja, hingga ritus Gallican, Mozarbic, dan juga ritu-ritus dari Gereja-gereja timur. ${ }^{21}$ Menurut Bishop tidak mungkin bisa memastikan yang mana ritus Romawi yang asli dan mana yang bukan. Yang mungkin bisa dilacak adalah hanya 'spirit' (semangat) yang menjadi dasar penggerak ritus Romawi yang akhirnya sering dikenal menjadi ciri ritus liturgi Romawi.

Sejalan dengan Bishop, para ahli sejarah liturgi juga menemukan bahwa pada abad pertama hingga abad keempat, liturgi Romawi sarat dengan improvisasi. Liturgi umumnya dirayakan secara spontan dan improvisasi. Abad pertama hingga keempat tempat martiria jauh lebih penting dan utama daripada liturgia. ${ }^{22}$ Sejak abad keempat hingga abad kedelapan ditandai dengan percampuran dan pertukaran ritus dan rumusan formula liturgi sebagai akibat dari munculnya tradisi ziarah (pilgrimage) dalam Gereja khususnya sejak Helena mengunjungi Yerusalem dan mendirikan situs-situs ziarah di tempat di mana Yesus pernah hadir dan hidup. Para peziarah dari berbagai tempat membawa tradisi dan kebiasaan gereja-gereja lokal ke tempattempat ziarah dan saling berinteraksi satu sama lain. Kemudian interaksi itu saling mempengaruhi hingga muncullah sangat banyak bentuk ekspresi iman, ritus dan formula doa liturgi baru. Pada abad keenam (769) terjadi Romanisasi liturgi karena Kaisar di Roma yakni Karolus Agung menetapkan bahwa liturgi harus dirayakan secara seragam di seluruh wilayah kekuasaan Kaisar. Penyeragaman yang diterapkan oleh Karolus Agung ditempuh dengan cara mengadopsi dan mengompilasi berbagai ritus, tradisi, formula dan rumusanrumusan liturgi dari berbagai macam tradisi dan gereja. Proyek ini sangat ambisius dan memberi warna tersendiri pada Gereja Katolik Roma, meskipun pada akhirnya keseragaman liturgi yang direncanakan itu memang tidak pernah berhasil 100\% karena Gereja-gereja lokal yang jauh dari Roma tetap mempunyai kebutuhan dan pemahaman ekspresi iman yang berbeda-beda. Kebutuhan-kebutuhan praktis umat dan refleksi iman umat atas pengalaman hidup ternyata tidak pernah bisa diseragamkan. ${ }^{23}$

Edmund Bishop menemukan bahwa ritus litrugi Romawi pada abad pertengahan ternyata berasal dari ritus liturgi Gereja di Prancis (Gallican rite) sekitar abad keenam sampai kedelapan, sementara Ritus Gereja Prancis (Gallican rite) abad keenam sampai kedelapan itu sendiri ternyata dibawa oleh para peziarah dari kota Roma pada abad-abad sebelumnya. Sementara itu, menurut Bishop, Gereja di Roma sendiri sejak awal gereja perdana selalu

21 Ibid., 4-8.

22 Edward Foley, From Age to Age: How Christians Have Celebrated the Eucharist (Collegeville, MN: Liturgical Press, 2008), 39-42, 69.

23 Ibid. 
mengadopsi ritus liturgi dari berbagai budaya dan tradisi Gereja-gereja yang dibawa oleh para peziarah ke Roma. Bishop mengatakan bahwa sejak awal abad pertama hingga abad pertengahan sebenarnya tidak pernah ada bukti yang meyakinkan tentang apakah ada atau tidak ritus liturgi yang dapat dikatakan sungguh murni ritus Romawi. ${ }^{24}$

Setelah abad pertengahan, yakni abad reformasi/kontra-reformasi, Gereja Katolik menjadi sangat responsive terhadap gerakan Protestantisme dengan mengadakan Konsili Trente, dan itu berdampak juga pada Liturgi. Prinsipnya ialah, teologi dan perayaan Liturgi pada abad pertengahan tetap dipertahankan dan bahkan dipertegas dan diawasi secara ketat agar tidak 'terkontaminasi' oleh ajaran Protestan. Kontrol terhadap ritus-ritus Liturgi diterapkan dengan cara merumuskan dan mencetak buku-buku perayaan Liturgi lengkap dengan rubrik-rubriknya yang sangat detail. Ritus Liturgi yang direstui oleh Konsili Trente itu biasanya kita kenal dengan istilah Missa Tredentine. ${ }^{25}$ Setelah Konsili Vatican II perayaan liturgi Ekaristi sudah berubah seperti yang kita rayakan sekarang dan Missa Tredentine sudah banyak ditinggalkan, meskipun pada ahir-ahir ini ada gerakan baru ingin kembali lagi menggalakkan Missa Tredentine.

Edmund Bishop akhirnya sampai pada kesimpulan bahwa tidak ada Ritus Romawi yang 'asli'. ${ }^{26}$ Sepanjang karier akademisnya sebagai seorang sejarawan liturgi, dia tidak menemukan apakah ritus Romawi yang asli itu pernah ada. ${ }^{27}$ Ritus yang sejak abad pertama dikenal dengan Ritus Romawi selalu merupakan hasil kompilasi dari berbagai tradisi dan budaya Gerejagereja yang dibawa ke Roma. Meskipun Bishop menyimpulkan bahwa ritus Romawi yang asli itu tidak ada, dia mengatakan bahwa ritus Liturgi Romawi mempunyai karakter asli dan asali yang seharusnya slalu mewarnai ritusritus liturgi Romawi sejak awal Gereja hingga awal abad ke 20 (Tredentine era) dst. Karakter asli dan asali itu seharusnya menjadi spirit atau semangat penggerak liturgi Romawi sepanjang masa. Spirit atau semangat penggerak itulah dia sebut dengan istilah the Genius. Bishop mengatakan the Genius of the Roman Rite (karakter dari spirit penggerak Ritus Liturgi Romawi) ialah: (1) Simple: sederhana; (2) Soberness: Tidak dibuat-buat, tidak berpura-pura; (3) Senses: mempunyai makna yang bisa ditangkap. ${ }^{28}$

\section{Kesimpulan dan Relevansi}

Dari liturgi bangsa Israel, kita dibantu merefleksikan juga liturgi Gereja

24 Bishop, "The Genius of the Roman Rite", 4-6, 13-18.

25 Bishop, "The Genius of the Roman Rite," 13-18. See, Foley, From Age to Age, 289-293.

26 Bishop, "The Genius of the Roman Rite," 18-19.

27 Ibid.

28 Ibid., 19. 
dan teologi saat ini, karena kita tidak bisa membantah bahwa Liturgi (dan teologi) kita juga berakar dari liturgi dan tradisi bangsa Yahudi. Bahkan Yesus sendiri ikut dan terlibat dalam liturgi dan budaya Yahudi pada zaman-Nya. Dari liturgi bangsa Israel kita diingatkan bahwa pada prinsipnya kita tidak menggunakan liturgi sebagai ekspresi iman untuk melestarikan masa lalu. Seperti halnya bangsa Israel, kita tidak menggunakan liturgi untuk mempertahankan ritual itu sendiri. Kita tidak menggunakan liturgi untuk mempertahankan perayaan-perayaan pesta masa lampau atau peristiwa masa lalu. Teks-teks Kitab Suci Perjanjian Lama dan Baru yang kita miliki tidak kita pakai sebagai teks sejarah atau original event' (peristiwa asli). Kitab Suci adalah buku iman yang menunjukkan kepada kita maksud yang asli dari Allah (the original purpose) yaitu: Allah menyelamatkan kita. Childs mengingatkan agar kita tidak mengeksploitasi teks-teks Kitab Suci untuk pembenaran ritus-ritus liturgi, dan juga tidak mengeksploitasi liturgi untuk kepentingan perasaan dan nostalgia masa lalu. Liturgi yang dipahami oleh Childs adalah perayaan iman akan kehadiran keselamatan dari Allah hari ini di sini. Dari Childs kita menemukan bahwa pengalaman dan ekspresi iman kita itu banyak dan bervariasi, akan tetapi tindakan Allah itu hanya satu, yaitu: Allah menyelamatkan, dan tindakan kurban Yesus di salib itu hanya satu kali untuk semua bangsa di segala zaman.

Dari tradisi liturgi bangsa Yahudi, kita diingatkan akan kualitas karya keselamatan yang kita rayakan dalam liturgi Gereja saat ini sama dengan yang ada pada liturgi di masa-masa lampau. Masa lampau Gereja tidak lebih istimewa dari masa kini. Allah mengasihi umat-Nya di masa sekarang ini sama seperti Dia mengasihi umat-Nya di masa lampau. Karena di hadapan Allah tidak ada jemaat masa lampau dan jemaat masa depan, semua generasi manusia hadir dan ada dihadapan-Nya. Kita perlu hati-hati dengan konsep/ definisi liturgi yang "asli" teristimewa bila konsep "asli" yang dimaksudkan selalu diidentikkan dengan peristiwa yang terjadi di masa lampau, atau peristiwa yang terjadi di 'luar negeri' (di Roma, di Yerusalem, di Eropa, dll), lalu menganggap semua yang dari luar itulah yang paling benar, sedangkan apa yang terjadi sekarang dan di sini (hic et nunc) dianggap duplikasi atau tiruan. Tidak jarang kita kurang menghargai rahmat Allah yang ada 'masa kini' dan di 'sini'.

Tidak ada 'original event' (peristiwa asli) dalam Kitab Suci yang dapat digunakan sebagai model/patron dan dijadikan standar ritual atau standar rumusan formula liturgi. Kisah Malam Perjamuan Terakhir tidak dapat digunakan sebagai model yang pakem atau patron standar perayaan Ekaristi karena satu peristiwa yakni kisah Malam Perjamuan Terakhir bukanlah titik puncak dari karya Allah, melainkan saksi atas karya keselamatan dari Allah, ${ }^{29}$ dan peristiwa itu menunjuk kepada nilai luhur karya keselamatan dari Allah

29 Xavier Léon-Dufour, Sharing the Eucharistic Bread, 94-95. 
dalam diri Yesus. Kita merayakan liturgi saat ini bukan karna salah satu generasi Gereja di masa lampau diselamatkan Tuhan dan pernah merayakan "Perjamuan" di masa lampau bersama Yesus saat Malam Perjamuan Tuhan. Keselamatan dari Tuhan dianugerahkan untuk semua generasi. Generasi Gereja pada zaman para Rasul tidak lebih istimewa dari generasi zaman kita sekarang, dan juga generasi Gereja yang ada di Roma, di Yerusalem atau di Eropa dengan sejarah Gereja yang cukup tua tidak lebih istimewa dari generasi Gereja di Indonesia, atau Asia, dst.

Ambisi yang terlalu berlebihan dalam mengagung-agungkan suatu ritus/ ritual liturgi sebagai ritus asli (original event) bisa merusak liturgi itu sendiri, menjebak umat masuk ke dalam berhala ritual atau berhala liturgi, karena hanya akan membawa umat sampai pada ritus liturgi itu sendiri dan tidak mengantarnya masuk ke dalam original purpose dari Allah, yaitu keselamatan sejati. Liturgi bukan sekedar imajinasi dan rasa haru/bahagia. Dari pengalaman Karolus Agung kita juga belajar bahwa kebutuhan-kebutuhan praktis umat dan refleksi iman umat atas pengalaman hidup ternyata tidak pernah bisa diseragamkan, dan tentunya itu nantinya berdampak pada praktik liturginya juga.

Ritus liturgi Romawi adalah simple: maksudnya ialah pada dasarnya liturgi Romawi itu sederhana dan tidak rumit sehingga memungkinkan bagi semua umat dari berbagai latar belakang untuk terlibat secara aktif sesuai dengan peranan masing-masing, tanpa ada yang diisolasi dan tanpa ada yang lebih dominan, bahkan umat yang paling sederhana pun merasakan bahwa perayaan itu adalah miliknya dan dia merasa dan menyadari bahwa dia disapa dalam imannya. Liturgi Romawi itu adalah soberness, artinya liturgi Romawi itu tidak dibuat-buat dan tidak berpura-pura. Semua yang hadir merayakan liturgi dengan sadar dan jujur, tidak berpura-pura saat melakukan ritus liturgi. Karakter lainnya dari Liturgi Romawi ialahSenses: liturgi yang kita rayakan itu mempunyai makna untuk kehidupan. Liturgi kita itu mengandung makna dan kesadaran iman yang bisa ditangkap. Saat merayakan liturgi, kita tidak sedang merayakan sesuatu yang misterius dan asing sama sekali, melainkan kita sedang merayakan realitas kehidupan kita di sini dan saat ini dalam terang iman. Jangan sampai liturgi sampai membuat kita menjadi orang asing atau orang aneh.

Polemik seputar "original events" dan "original purpose" yang diangkat oleh Brevard S, Childs telah berhasil menarik perhatian para pemerhati liturgi untuk mencari apa sebenarnya karakter dasar Liturgi Romawi yang menjadi ciri khas Liturgi Romawi. Ciri khas Liturgi yang baik tidak terletak pada seberapa akurat suatu peraturan liturgi dilaksanakan, juga bukan soal seberapa megah perayaan liturgi dirayakan, dan bukan soal seberapa indah/bagus lagu dan dekorasi liturgi dikemas. Perayaan liturgi dikatakan baik bila perayaan itu mempunyai dampak bagi hidup umat yang merayakannya, mampu membangkitkan kesadaran iman yang benar serta mampu mengubah 
hidup umat menjadi lebih baik. Ketika perayaan liturgi tidak mampu mendukung/mengubah hidup umat menjadi semakin baik dan benar maka liturgi itu tidak mempunyai 'power'.

\section{Kepustakaan}

Bishop, Edmund. "The Genius of the Roman Rite". Liturgica Historica: Paper on the Liturgy and Religious Life of the Western Church. Oxford: Clarendon Press, 1918,1962.

Bradshaw, Paul. Eucharistic Origins. London: SPCK, 2004.

. The Search for the Origins of Christian Worship: Source and Methods for the Study of Early Liturgy. $2^{\text {nd }}$ ed. London: SPCK, 2002.

Bradshaw, Paul F., and Maxwell E. Johnson. The Eucharistic liturgies: their Evolution and Interpretation. Collegeville, MN: Liturgical Press, 2012.

Bradshaw, Paul F. and Lawrence A. Hoffman, ed. The Making of Jewish and Christian Worship. Notre Dame, IN: University of Notre Dame, 1991.

Chase, Nathan P. "Liturgical Preservation, Innovation, and Exchange at the Crossroads of the Visigothic and Merovingian Kingdoms." Worship, 92 (September 2018): 415-435.

Childs, Brevard S. Exodus: A Commentary. London: SCM Press, 1974.

. Introduction to the Old Testament as Scripture. Philadelphia: Fortress Press, 2011.

. Memory and Tradition in Israel. London: SCM Press, 1962.

. Old Testament Theology in A Canonical Context. London: SCM Press, 1985.

. "Critique of Recent Intertextual Canonical Interpretation." Zeitschrift fur die Alttestamentliche Wissenschaft Vol . 115, no 2 (2003): 173-184.

Foley, Edward. From Age to Age: How Christians Have Celebrated the Eucharist. Collegeville, Minnesota: Liturgical Press, 2008.

Hadley, Christopher M. "The Archetypal Faith of Christ." Theological Studies 81. No.3 (September 2020): 671-692.

Jeremias, Joachim. The Eucharistic Words of Jesus. London: SCM Press, 1966.

Lamberts, Jozef. "Some Questions about the Consecration." Worship 94 (January 2020): 50-66.

Léon-Dufour, Xavier. Dictionary of the New Testament. Translated by Terrence Prendergast. London: Geoffrey Chapman, 1980. 